\title{
THE EFFECTS OF AFFORESTATION PROGRAMS IN HEVES COUNTY BETWEEN 2007 AND 2013
}

\author{
Tibor BENCZE ${ }^{1}$, GÁbOR KONCZ ${ }^{2}$
}

\author{
${ }^{1}$ Government Office of Heves County, Department of Agricultural and Rural Development \\ Support, Eger, Hungary \\ ${ }^{2}$ Eszterházy Károly University, Faculty of Agricultural Sciences and Rural Development, \\ Institute of Rural Development and Lanscape Management, Gyöngyös, Hungary \\ bence.tibee@gmail.com
}

\begin{abstract}
The forest is one of the most complex natural ecosystems that is one of the basic living conditions of the healthy human life due to its effects on the environment. According to their functions forests can fill security, economic, social, health, tourism, and education as well as research roles.

After the end of World War I the level of forest cover decreased to $11.8 \%$ in Hungary. At this time Hungary was Europe's fourth poorest country in forest and tree. The increasing of forest cover was an important objective in each areas since then.

The location and the size of the afforested area ultimately will be appointed by the landowners' intentions. The state can support the success of the afforestation program by various devices, and promote effectively the enforcement of public interest. The New Hungary Rural Development Programme (2007-2013) envisaged the deployment of 69,000 hectares of new forest, of which $70 \%$ were implemented. Under the measure support was granted for the first afforestation of areas withdrawn from agricultural cultivation.

Despite the above average extent of forest covers in Heves County (24.5\% in 2006), further opportunities were opened to increase the forest area. In afforestation terms the high priority regions includes the poor quality arable lands of feet of Mátra and Bükk mountains and the reclamation areas of Visonta open-cast lignite mine in Heves County.

During the research, we worked on secondary databases with a view to examine how regional differences there are in within Heves County in the case of location of forest areas and implemented forest plantations. On the one hand we used the data of Forestry Directorate of the National Food Chain Safety Office, on the other hand we worked up the statistics of Agricultural and Rural Development Agency about afforestation subsidies supported in the framework of New Hungary Rural Development Programme (2007-2013).

There are significant differences among the districts of Heves County regarding the extent of forest cover between upland and lowland areas. While Pétervására and Bélapátfalva districts were characterized by $61 \%$ and $59 \%$ forest cover in 2006, at the same time in Füzesabony, Heves and Hatvan districts the same value was slightly higher than 4\%. In the period between 2006 and 2015 the rate of forestation increased in all districts of the County at least by 0.2 percent. The growth rate was more than one percent in Pétervására and Gyöngyös district. Therefore, a significant expanse of land that is less suitable for agricultural cultivation has given a new function.
\end{abstract}

Keywords: forests role, afforestation process, rural development subsidies, Heves County, regional differences

\section{INTRODUCTION}

Forest is one of the most complex natural ecosystems that, because of its environmental impact, is one of the basic living conditions of healthy human life. In addition to the conservation effects that are often regarded as natural, but with enormous economic value, those also produce raw materials and food as renewable natural resources. Its significance is not negligible in terms of livelihoods for the rural population. The purpose of the forests can be protective, economic, health-social, tourism as well as education and research (SELBY ET AL., 2005, FEJES AND RESTYÁNSZKINÉ JACZKÓ, 2013).

With the peace treaty of Trianon ending the First World War, Hungary lost the 84 percent of the forests of former country territory. The previous $26-27 \%$ forest density decreased to 
$11.8 \%$ in Hungary, making it the fourth poorest country in the woods in Europe. A new forestry policy has been developed in line with the radically changed social, economic and natural environment. There were two simple, clear principles that are valid until today. The first was the protection of the existing forests, improvement of their naturalness and structure. The second was to increase the country's forests by installing new forests, especially in the unwooded Great Plain (MAGYAR, 1961, GÁL AND KÁLDY, 1977).

The expansion of forestry has been a development priority in each of the last decades. Most of the afforestation was built on poor arable land or pasture that is less suitable for agricultural cultivation. So, it also played a significant role in the restructuring of agriculture (BABINYEC ET AL., 2015).

The place and size of the area to be afforested is ultimately determined by the will of the landowners. So, for a successful implementation of an afforestation programme the state has to influence it by most supportive tools, to promote public interest effectively. Most of the forests proposed for implementation are among the forests of primarily economic use. At the same time, in many places, the enforcement of public goals is determinative, such as soil and landscape protection (For example in the case of recultivation of surface mines), as well as flood and inland water protection (ZANCHI ET AL., 2007, NAABURS ET AL., 2015). The Afforestation Programme formulated long-term (about 35-50 years) objective. The realization of which is to increase the country's forests to $27 \%$ as optimum at the time when the programme was prepared. It should be emphasized that reviewing the definition of optimal national forest level will be again timely in the near future because of fast changing environmental conditions (JANKÓ, 2013).

The New Hungary Rural Development Programme has foreseeing the installation of a new forest of 69000 hectares for 2007-2013. On the other hand the realization was 46300 ha, which meant nearly $70 \%$ fulfilments. The willingness to afforestation was largely influenced by the following factors: loss of SAPS entitlement, increasing demand for food, initial difficulties in the support system. For forestry purposes approximately 88 billion HUF was paid and committed by the end of 2015, which is also successful in EU comparisons.

The support system cannot be considered as sources of development and profitability for farming in the case of forestry thinking over longer term due to uncertainties in EU funding after 2020. The introduction and elaboration of alternative solutions (preparation of measures) is already required, particularly as a result of mitigating the effects of climate change (EU, 2003, NAABURS ET AL., 2015).

\section{MATERIAL AND METHOD}

Our research focused on Heves County. In its territory there are significant differences in degree of forest cover and the possibilities of further afforestation by reason of varied terrain and geological conditions. In sum, mountainous areas result in higher forest cover than the national average. The dominant tree species in the mountainous and hilly areas are oaks and beech. The non-native acacia is present in the flat countryside and in the hillsides (DÖVÉNYI, 2010). About 50\% of the forest areas are owned by the state and managed by a state-owned joint stock company (Egererdö). Forests are characteristic of certain parts of the county, where its share have grown in the last 20 years, but growth has lagged behind national trends. Surveying of sites for afforestation was carried out in 2006 in connection with the modification of National Spatial Plan. The most important aspect of that study was economy and environmental sensitivity. Other important influencing factors were the 
soil type of the site and waterhouse maintenance. It has been established that there is still a significant area available for afforestation in the county.

To explore the subject we have chosen to process secondary databases. Our primary goal was to point out the territorial differences within Heves County with respect to forest areas, afforestation and afforestation specifically under the New Hungary Rural Development Programme (2007-2013). On the other hand, we wanted to point out the purpose of the forests and the purpose for which they have been created in recent years in regions with different abilities. On the one hand we used the data of Forestry Directorate of the National Food Chain Safety Office. On the other hand we worked up the statistics of Agricultural and Rural Development Agency about afforestation subsidies supported in the framework of environmental protection measures of NHRDP.

\section{RESULTS}

From the end of 2006 to the end of 2015 the area of Hungary covered by woodland increased from $19,928 \mathrm{~km}^{2}$ to $20,551 \mathrm{~km}^{2}$, which means $3.1 \%$ increase over 9 years. In Heves County, this change was somewhat lower $(2.7 \%)$. At the end of the period under review, the extent of the forests of Hungary is $22.1 \%$. Data from Heves County $(25.2 \%)$ still exceed the national average, in the order of counties occupies a middle field position. In the North Hungary Region Borsod-Abaúj-Zemplén and Nógrád County's forest cover are also higher.

The districts of Heves County features very different degree of forest share. Pétervására and Bélapátfalva districts are characterized by outstanding data. The Eger and Gyöngyös districts are characterized by multi-coloured relief elements, that resulting in moderately high values. The area of the other three districts is already dominated by the lowlands, where the share of the forest is very low due to the decisive role of agriculture (Table 1).

Table 1. The forest cover of Heves County districts

\begin{tabular}{|l|c|r|c|}
\hline \multirow{2}{*}{ Districts } & \multicolumn{2}{|c|}{ Forest cover (\%) } & \multirow{2}{*}{ Area $\left.\mathbf{( k m}^{\mathbf{2}}\right)$} \\
\cline { 2 - 3 } & $\mathbf{2 0 0 6}$ & $\mathbf{2 0 1 5}$ & \\
\hline Bélapátfalva & 58.8 & 59.1 & 180.9 \\
\hline Eger & 36.6 & 37.2 & 602.1 \\
\hline Füzesabony & 4.0 & 4.2 & 578.6 \\
\hline Gyöngyös & 27.4 & 28.6 & 750.8 \\
\hline Hatvan & 4.4 & 4.6 & 352.2 \\
\hline Heves & 4.2 & 4.7 & 697.6 \\
\hline Pétervására & 61.2 & 62.4 & 475.1 \\
\hline County total & 24.5 & 25.2 & 3637.2 \\
\hline
\end{tabular}

Source: Forestry Directorate of the National Food Chain Safety Office, 2006 \& 2015.

The change in the degree of forestry is fundamentally influenced by the forest cover of districts at the beginning of the examined period. The high degree of forestry in Bélapátfalva and Pétervására districts has already been well suited to the geographic features. In absolute terms, the largest expansion of forest was observed in the Gyöngyös district by 880 ha. At the same time, the 303-hectare expansion in the Heves district meant a $10 \%$ increase in the forest covered area. In this lowland region, the unfavourable soil conditions justify the further expansion of the forest area. The expansion was $4 \%$ in the Hatvan and Füzesabony regions characterized by better soil conditions. However, the area of energy plantations may continue to grow in the future in these areas too. 
The number one purpose of forests in Heves County is wood production by $47.6 \%$ proportion (Figure 1). The nature conservation has the second largest significance, these forests cover the $37.9 \%$ of forest area. On the steep hillside the soil protection gets more important role $(10 \%)$. Many additional protection features are displayed, which are characterized by a smaller share than $1 \%$.

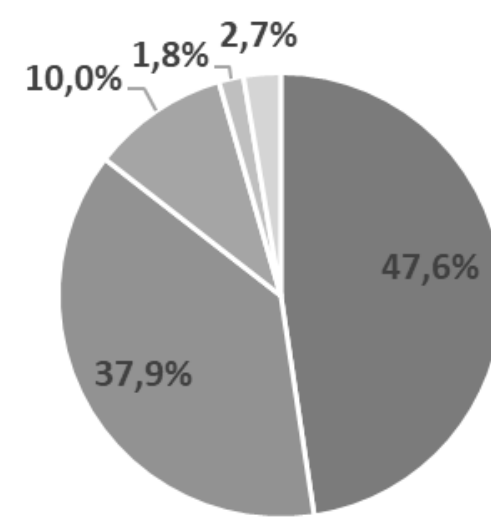

$$
\begin{aligned}
& \text { - Wood-producing forest } \\
& \text { - Soil protection forest } \\
& \text { - Other }
\end{aligned}
$$$$
\text { - Nature conservation forest }
$$$$
\text { - Forest park }
$$

\section{Figure 1. The distribution of forests according to their purpose in Heves County}

Source: Forestry Directorate of the National Food Chain Safety Office, 2015.

The afforestation statistics are included areas designated for refurbishment and area of new installations of forest. The extension of refurbishment usually an order of magnitude greater than the new installations. The degree of afforestation has changed considerably in years of the period 2008-2015. The volume of new installations nationwide in 2008 and in 2009 exceeded 4000 hectares. However, the share of Heves County had only a little more than $1 \%$ in these years. Except for 2012, in the coming years continuously decreased the size of the areas under construction. The most affected were the Great Plain counties such as Szabolcs-Szatmár-Bereg and Bács-Kiskun. In these counties, in the case of sandy-gravel farmlands, the afforestation is justified in terms of economic and protection too. In Heves County the most significant new areas were taken off in the Heves district (124 ha), followed by Hatvan (59 ha) and Gyöngyös (45 ha) districts (Figure 2).

In context with afforestation of agricultural land the farmers could have submitted a grant application for grooming afforestation up to 5 years and to compensate for loss of income due to afforestation up to 15 years. Based on the amount of grants awarded, the years of 2009 (37.5\%) and 2011 (31.7\%) were the most significant in the county between 2007 and 2013. The districts, where forested areas represent high proportion hardly got support. The most outstanding support arrived to the Heves district. Furthermore poor quality arable lands were afforested around Eger (Figure 3). 


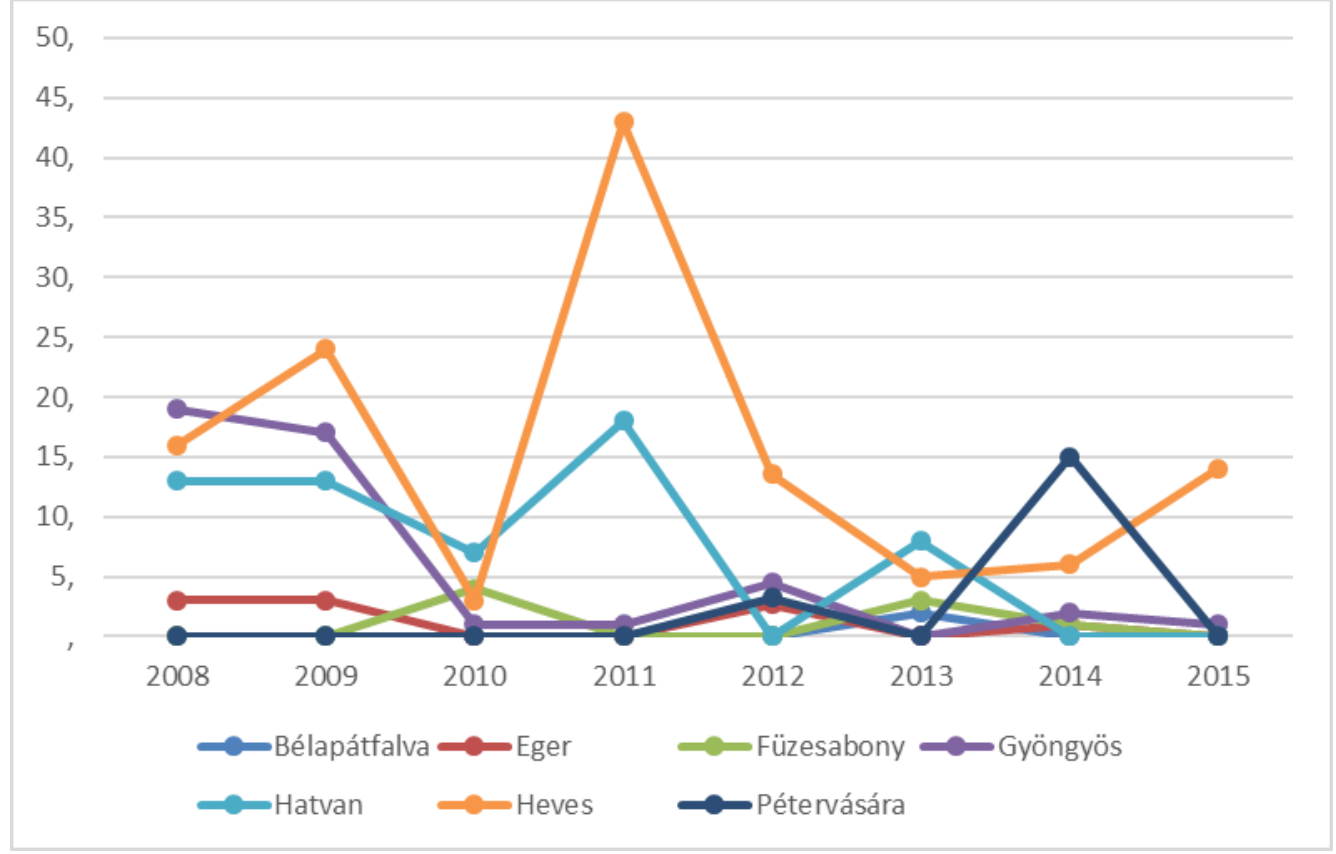

Figure 2. New afforestation (ha) between 2008 and 2015

Source: Forestry Directorate of the National Food Chain Safety Office, 2015.

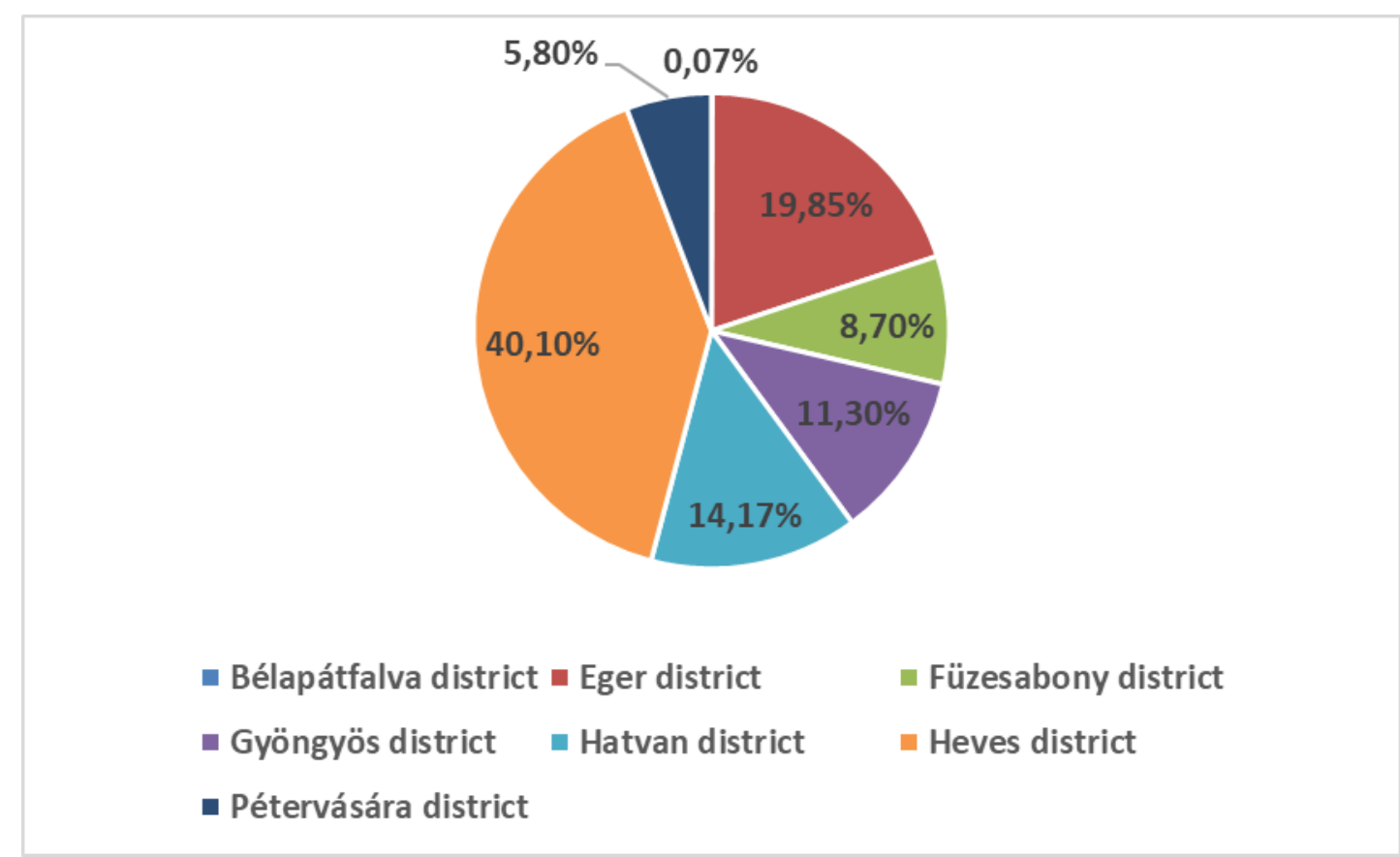

Figure 3. Subsidies for the afforestation of agricultural areas - Share of districts on the basis of subsidized amount (2007-2013)

Source: Agricultural and Rural Development Agency, 2007-2013.

\section{CONCLUSIONS}

Expansion of forest areas has been a development priority in Hungary for decades and to the present day. The afforestation is justified by several reasons, such as functional change of unproductive arable lands and meadows, better utilization of forest soils especially in mountainous areas and re-utilization of recultivation areas. 
Heves County is characterized by above average forest share primarily due to mountainous areas as Mátra and Bükk. That is why there are huge differences between the northern and southern parts of the county from perspective of the location of forests. In the southern part of the county it is possible to afforest significant areas, but it will be supported by owners in case of areas with poor soil conditions and favorable subsidy conditions.

Therefore, the scheduling of afforestation of agricultural land was lagging behind in the past years. While in the county, the former territorial differences slightly decreased between mountainous and plain areas. Thus, adapting more to agro-ecological conditions and increasing income opportunities in rural areas.

\section{REFERENCES}

BABINYEC, F. ET AL. (2015): Erdővagyon és erdőgazdálkodás Magyarországon. NÉBIH Erdészeti Igazgatóság, Budapest, $4 \mathrm{p}$.

DöVÉNYI, Z. (ED.) (2010): Magyarország kistájainak katasztere. MTA Földrajztudományi Kutatóintézet, Budapest.

EUROPEAN COMMISSION (2003): Sustainable forestry and the European Union - Initiatives of the European Commission. Luxembourg: Office for Official Publications of the European Communities, $56 \mathrm{p}$.

FEJES, L.; RESTYÁNSZKINÉ JACZKÓ, V. (2013): Az erdőgazdálkodás jellemzői. = Statisztikai Tükör 7(95): 6 .

GÁL, J.; KÁLDY, J. (1977): Erdősítés. - Akadémiai Kiadó, Budapest, 640 p.

JANKÓ, F. (2013): Elfeledett viták az alföldi erdősítés és vízrendezés éghajlati hatásairól. = Földrajzi Közlemények 137(1), pp. 51-63.

MagYAR, P. (1961): Alföldfásítás II. Akadémiai Kiadó, Budapest, 622 p.

NABUURS, G. ET AL. (2015): A new role for forests and the forest sector in the EU post2020 climate targets. European Forest Institute, 29 p.

Selby, A.; PetÄJIStÖ, L.; Koskela, T. (2005): Forests and afforestation in a rural development context: a comparative study of three regions in Finland. Working Papers of the Finnish Forest Research Institute 14: 75.

ZANCHI, G.; ThIEL, D.; Green, T.; LinDNER, M. (2007): Afforestation in Europe. - Impact of Environmental Agreements on the CAP (Specific targeted research project), $41 \mathrm{p}$. 